УДК 339:677(477)

Волинчук Ю.В., к.е.н., доцент

Volynchuk Yu. Candidate of Economic Sciences, Associate Professor https://orcid.org/0000-0002-3604-8677

Нікітін T.O.

Nikitin T.

Student

\title{
АНАЛІТИЧНЕ ДОСЛІДЖЕННЯ РИНКУ ТОВАРІВ ЛЕГКОЇ ПРОМИСЛОВОСТІ УКРАЇНИ
}

\author{
Луиьький національний технічний університет
}

\begin{abstract}
У статті викладено авторське дослідження ринку товарів легкої промисловості України, актуальність проведення якого зумовлена суперечливістю цифрових даних, значною кількістю нелегального імпорту та тіньового виробництва товарів легкої промисловості.

Проаналізовано географію та структуру експортно-імпортних відносин товарів легкої промисловості. В зовнішньоекономічній діяльності виокремлено та досліджено товари легкої промисловості за трьома групами, зокрема, шкури необроблені та шкіра вичинена; текстильні матеріали та текстильні вироби (найбільш вагома група); взуття, головні убори, парасольки та оброблені пух та пір'я. Висвітлено динаміку та товарну структуру роздрібного та оптового товарообороту, індекси фізичного обсягу роздрібного товарообороту підприємств роздрібної торгівлі за товарними групами в регіональному розрізі тощо.

Стан ринку товарів легкої промисловості вітчизняного виробництва визначено як малорозвинутий. Водночас конкуренцію на ринку України можна оцінювати як високу, адже товари низького цінового сегменту значною мірою покриваються експортом з Китаю та Туреччини, а високого брендовими виробниками з країн СС. Труднощі також зумовлені присутністю великої частки тіньового виробництва, торгівлею контрабандними товарами та активним споживанням населенням секонд-хенду.

Доведено, що пандемія Covid-19 в українських реаліях засвідчила значний потенціал середнього та малого бізнесу в напрямку швидкої адаптації до новітніх потреб ринку (виготовлення масок, захисних костюмів тощо). Обгрунтовано, що для розвитку підприємствам слід активно співпрацювати в Українській асоціації підприємств легкої промисловості, інвестувати в оновлення власних виробничих потужностей та професійне навчання персоналу. Визначено, що з позицій держави, основними підтримуючими заходами в сфері розвитку виробництва та торгівлі товарами легкої промисловості повинні бути детінізація ринку, зменшення потоків вживаних речей, захист національних виробників тощо.
\end{abstract}

Ключові слова: легка промисловість, торгівля, ринок, товари, експорт, імпорт, регіони, аналіз.

\section{ANALYTICAL RESEARCH OF UKRAINE'S MARKET OF LIGHT INDUSTRY PRODUCTS}

\section{Lutsk National Technical University}

The article presents the author's research of the market of light industry goods of Ukraine, the urgency of which is conditioned by the inconsistency of digital data, a significant amount of illegal imports and shadow production of light industry goods.

The geography and the structure of export-import relations of light industry goods are analyzed. In foreign economic activity the goods of light industry are allocated and investigated for 3 groups, in particular leather products; textile materials and textile products (the most important group); shoes, hats, umbrellas, processed down and feathers. The dynamics and commodity structure of retail and wholesale trade turnover, volume indices of retail trade turnover by product groups in the regional context, etc. are clarified.

The state of the market of light industry goods of domestic production is defined as underdeveloped. At the same time, competition in the Ukrainian market can be assessed as high, as low-priced goods are largely covered by exports from China and Turkey, and high - by branded manufacturers from EU countries. Difficulties are also conditioned by a large part of shadow production, trade in contraband goods and active consumption of second-hand goods.

It is proved that the Covid-19 pandemic in the Ukrainian realities has shown the significant potential of Small and medium-sized businesses in the direction of rapid adaptation to the latest market needs ( masks of protective suits production). It is substantiated that for the development of enterprises it is necessary to cooperate actively in the Ukrainian Association of Light Industry Enterprises, to invest in the renewal of their own production facilities and professional training of personnel. It is determined that from the standpoint of the state, the main 
supporting measures in the development of production and trade in light industry goods should be de-shadowing of the market, reduction of flows of second-hand goods, protection of national manufacturers, etc.

Key words: light industry, trade, market, goods, export, import, region, analysis.

Постановка проблеми у загальному вигляді i ïi зв'язок 3 важливими науковими та практичними завданнями. Виробництво та реалізація текстильних виробів і взуття в Україні останніми роками суттєво зменшуються, про що свідчить збільшення частки імпорту та зменшення частки експорту товарів легкої промисловості. Значна кількість виробленої та реалізованої продукції знаходиться в тіні, що значно послаблює розвиток галузі та зменшує кредит довіри з боку іноземних інвесторів. Низька частка впровадження інновацій на підприємствах галузі зумовлює зменшення ефективності виробництва та конкурентоспроможності вітчизняної продукції. Водночас ефективне функціонування підприємств легкої промисловості здатне забезпечити ріст виробництва та збалансування торгівлі товарами даної галузі, що вимагає дослідження стану розвитку торгівлі вітчизняного ринку текстильних товарів та взуття для формування нових векторів управління.

Аналіз останніх досліджень, у яких започатковано вирішення проблеми. Значну увагу проблемам розвитку ринку легкої промисловості приділяли такі науковці як О. Мірошниченко, М. Неліна та О. Феленюк, що досліджували можливості для експорту товарів українських підприємств до країн ЄС [1]. В. Бойко та К. Тарасова займались аналізом стану легкої промисловості України [2]. У науковій праці Л. Дейнеко [3] комплексно проаналізовані основні види переробної промисловості і легкої в тому числі. У статті Т. Гавриленко та І. Бродюк [4] розглянуто перспективи розвитку промисловості в умовах нестабільного зовнішнього середовища.

Водночас, дослідження ринку легкої промисловості в різних його торговельних аспектах, на нашу думку, недостатньо висвітлене в існуючих наукових працях. Це пов'язано із суперечливістю цифрових даних, значною кількістю нелегально імпортованих товарів легкої промисловості та тіньового виробництва, що обумовлює актуальність даного дослідження.

Цілями статті, зважаючи на викладене вище, $\epsilon$ аналітичне дослідження, узагальнення та систематизація основних даних, що характеризують розвиток торгівлі товарами легкої промисловості на ринку України з метою виявлення слабких сторін та точок росту цієї галузі.

Виклад основного матеріалу дослідження 3 повним обгрунтуванням отриманих наукових результатів. Легка промисловість - це галузь, яка забезпечує населення товарами першої необхідності. Станом на 2019 р. на території України (за даними Української Асоціації підприємств легкої промисловості) функціонує 2518 підприємств і 88 тис. працівників, зайнятих у даній сфері. В торговельному балансі зовнішньої торгівлі за 2019 р. товари легкої промисловості складають в імпорті 5,15\%, в експорті 2,37\% [5].

Для аналізу тенденцій розвитку торгівлі товарами легкої промисловості було розглянуто зовнішньоекономічну діяльність України, структуру та географію експортноімпортних відносин, обсяги роздрібної та оптової торгівлі в Україні.

Відповідно до даних Державної служби статистики України, в зовнішньоекономічній діяльності виокремлено 3 групи товарів легкої промисловості [6]:

- шкури необроблені, шкіра вичинена (вироби зі шкіри, шкури, натуральне та штучне хутро);

- текстильні матеріали та текстильні вироби (шовк, бавовна, вовна, нитки, килими, вата, тканини, одяг та інші готові вироби);

- взуття, головні убори, парасольки та оброблені пух та пір'я.

Структура товарного імпорту та експорту представлена в таблиці 1.

Як бачимо, найбільш вагомою за структурою групою товарів в 2019 р. (в експорті 71,51\% та імпорті 75,83\%) становлять матеріали та вироби з текстилю. Взуттєві вироби, 
головні убори та парасольки складають $15,9 \%$ і $15,13 \%$ товарного експорту та імпорту відповідно. Шкури необроблені та вичинені найменш вагома група, що займає $12,58 \%$ експорту та 9,04\% імпорту в 2019 році.

Таблиця 1

Питома вага зовнішньої торгівлі товарами легкої промисловості

\begin{tabular}{|l|c|c|c|c|c|c|}
\hline \multirow{2}{*}{$\begin{array}{l}\text { Код і назва товарів згідно 3 } \\
\text { УКТЗЕД }\end{array}$} & \multicolumn{2}{|c|}{$2018 \mathrm{p}$} & \multicolumn{2}{c|}{2019 р. } & \multicolumn{2}{c|}{$2019 / 2018$} \\
\cline { 2 - 7 } & Експорт & Імпорт & Експорт & Імпорт & Експорт & Імпорт \\
\hline $\begin{array}{l}\text { СІІІ. Шкури необроблені, } \\
\text { шкіра вичинена }\end{array}$ & 13,55 & $\begin{array}{c}\text { Структура } \\
\%\end{array}$ & $\begin{array}{c}\text { Структура } \\
\%\end{array}$ & $\begin{array}{c}\text { Структура } \\
\%\end{array}$ & 3міна у \% & 3міна у \% \\
\hline $\begin{array}{l}\text { ХІ. Текстильні матеріали та } \\
\text { текстильні вироби }\end{array}$ & 69,38 & 75,58 & 71,51 & 75,83 & 2,13 & $-1,66$ \\
\hline $\begin{array}{l}\text { ХІІ. Взуття, головні убори, } \\
\text { парасольки }\end{array}$ & 17,07 & 13,72 & 15,90 & 15,13 & $-1,17$ & 1,41 \\
\hline
\end{tabular}

Джерело: складено авторами на основі [6]

Баланс між експортно-імпортними операціями важливий показник, який в тому числі показує розвиток галузі. На рисунку 1 показано зовнішню торгівлю основними товарами легкої промисловості.

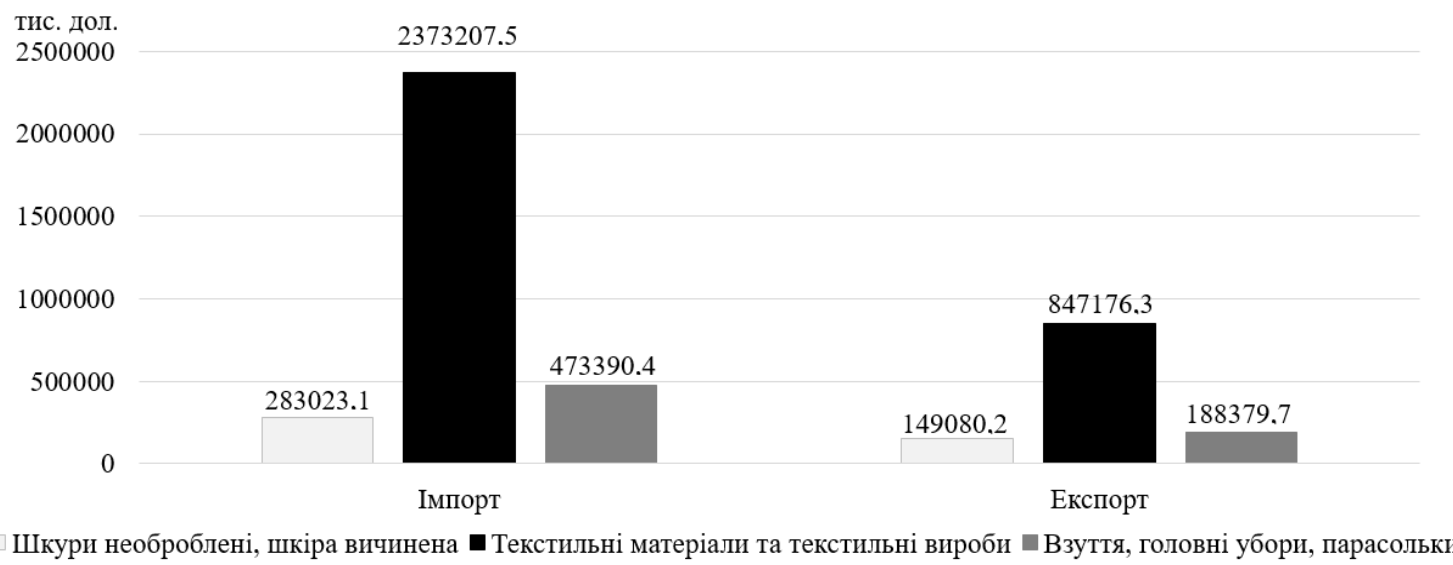

Рис. 1 Експорт та імпорт товарів легкої промисловості у 2019 р. [6]

Отже, зовнішня торгівля товарами легкої промисловості в Україні не $\epsilon$ збалансованою. Про це свідчить переважання імпорту над експортом, а саме в 2019 р. на 164\%, а в 2018 р. на 118\%. В 2019 р. спостерігається збільшення величини імпорту порівняно з попереднім роком на 17,5\% і зменшенням обсягу експорту на 2,9\%. Імпорт матеріалів та виробів з текстилю переважає над експортом в 2019 р. на 180\%, a 2018 р. на $138 \%$. Необроблені та вичинені шкіри експортуються менше чим імпортуються на 47\% та 42\% в 2019 р. і в 2018 р. відповідно. Взуття, головні убори та парасольки імпортуються більше на $151 \%$ та 75\% в 2019 р. та 2018 р. відповідно.

Географія експортно-імпортних відносин представлена в таблиці 2.

Отже, найбільшим імпортером товарів в Україну є Китай та Туреччина, що імпортують переважно сировину та товари невисокого цінового сегменту. Свропейські країни імпортують в основному готову продукції високої якості та вартості. Експорт 
українських товарів представлений готовою продукцією та сировиною до країн ЄС та СНД.

Таблиця 2

Найбільші експортери та імпортери України

\begin{tabular}{|c|c|c|}
\hline $\begin{array}{l}\text { Код і назва товарів } \\
\text { згідно УКТЗЕД }\end{array}$ & Імпорт & Експорт \\
\hline $\begin{array}{l}\text { VIII. Шкури необроблені, } \\
\text { шкіра вичинена }\end{array}$ & $\begin{array}{c}\text { Китай, Польща, Італія, Туреччина, } \\
\text { Франція, Уругвай }\end{array}$ & $\begin{array}{c}\text { Польща, Італія, Данія, Угорщина, } \\
\text { Німеччина, Франція }\end{array}$ \\
\hline $\begin{array}{l}\text { ХІ. Текстильні матеріали та } \\
\text { текстильні вироби }\end{array}$ & $\begin{array}{l}\text { Китай, Португалія, Німеччина, } \\
\text { Італія, Бангладеш, Білорусія }\end{array}$ & $\begin{array}{c}\text { Польща, Данія, Румунія, Франція, } \\
\text { Італія, Австрія }\end{array}$ \\
\hline $\begin{array}{l}\text { XII. Взуття, головні убори, } \\
\text { парасольки }\end{array}$ & $\begin{array}{c}\text { Китай, В'єтнам, Італія, Туреччина, } \\
\text { Індонезія, Польща }\end{array}$ & $\begin{array}{l}\text { Румунія, Польща, Італія, } \\
\text { Угорщина, Росія, Білорусь }\end{array}$ \\
\hline
\end{tabular}

Джерело: складено авторами на основі [7]

Україна активно розвиває міжнародні економічні зв'язки в галузі торгівлі товарами легкої промисловості. До прикладу, на міжнародній виставці одягу та взуття Toronto Shoe Show (Канада) були представлені наступні українські бренди: Andre TAN (жіночий дизайнерський одяг); Berserk Sport (спортивний одяг); Буквиця (чоловічий та жіночий одяг, аксесуари); AnnaFoxy (жіночий casual одяг, білизна, аксесуари) та інші. У взуттєвій галузі експорт здійснюють наступні бренди: Belsta (домашнє взуття), Caman (чоловіче, жіноче та спортивне взуття), KaDar (чоловіче та жіноче взуття в стилі casual), Krok (військове взуття) [12].

На внутрішньому ринку товарів легкої промисловості спостерігається наступне. В 2017 р. секонд-хенд склав 54\% структури імпортних товарів, що у свою чергу призводить до втрати 45 тис. робочих місць (за даними Укрлегпрому). Україна також входить в топ-3 країн найбільших споживачів вживаного одягу та взуття в світі, що деструктивно впливає на розвиток торгівлі новими вітчизняними та імпортними товарами [1].

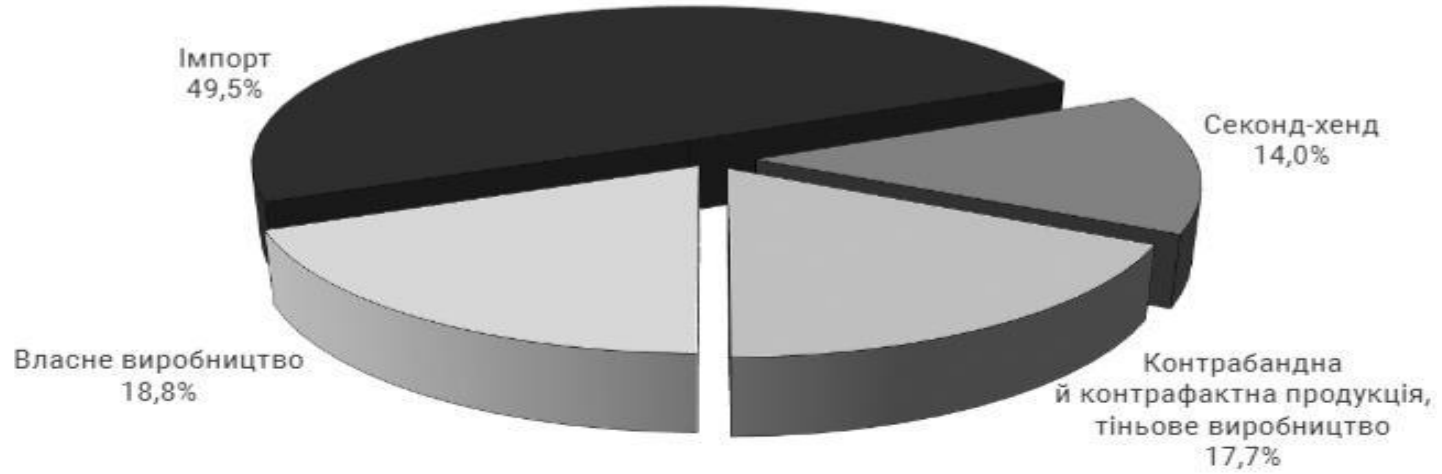

Рис. 2. Структура внутрішньої торгівлі України (складено авторами на основі

[1])

Головною проблемою секонд-хенду України є те, що значна частина гуманітарної допомоги надходить 3 країн СС безоплатно, проте перерозподіляється і продається в торговельних магазинах. Зокрема, за даними Мінсоцполітики [11], у 2019 р. було розглянуто 607 звернень про визнання гуманітарною допомогою вантажів, з яких 304 було визнано гуманітарною допомогою. Такі уряду свідчать про те, що існують корупційні схеми провезення вантажів без розмитнення як гуманітарної допомоги, які потім продаються за ринковими цінами. Більше того, в інтернеті процвітає торгівля уживаними речами з Свропи, що значно підвищує конкуренцію для вітчизняного виробника одягу та взуття. 
Крім вищезгаданого, за даними Укрлегпрому на українському ринку легкої промисловості присутні 17,7\% контрабанди та тіньового виробництва, що стосується переважно товарів секонд-хенду та підпільних виробництв товарів легкої промисловості. Це негативно впливає на розвиток виробництва та торгівлі вітчизняними товарами, оскільки ціна тіньової продукції нижча за виготовлену прозоро. Ця проблема більше стосується державного регулювання, проте стимулюючим фактором для процвітання тіньового бізнесу є зменшення купівельної спроможності споживачів [1].

Власне виробництво текстильних матеріалів - тканин в Україні зосереджено на наступних стратегічних підприємствах:

- «Чексіл» - чернігівське підприємство, яке щорічно виготовляє близько 5 млн погонних метрів шерстяних, камвольних тканин та суконь;

- Черкаський шовковий комбінат - на підприємстві виготовляється близько 8,6 млн м² змішаних і 3,8 млн м² бавовняних волокон;

- «Текстерно» - тернопільське підприємство, щорічно випускає 2,2 млн м ${ }^{2}$ бавовняних та змішаних волокон;

- Vladi - харківське підприємство, яке також має потужності в м. Березань, щорічний випуск шерстяних тканин, сукна та нетканих полотен складає 3 млн м² [13].

Виробництво одягу - найбільш суперечлива галузь, оскільки фактично відсутні чіткі дані щодо зайнятості населення в ній. Зокрема, за даними Укрлегпрому [5], дана галузь налічує 88 тис. працівників, а за іншими оцінками - близько 150 тис. зайнятих осіб. Тоді як у галузевій асоціації Globus Fashion Ukraine вважають, що 80\% підприємств не входять до даної статистики і реальна кількість працівників складає 500 тис. осіб. В цілому, галузь представлена великою кількістю малих та середніх підприємств [13].

Лідером у взуттєвій підгалузі легкої промисловості можна виділити СП ТОВ «РІФ-1», адже підприємства цього виробника розташовані в містах Бердичів, Житомир та Київ. Загальний щорічний обсяг виробництва продукції складає 2 млн пар взуття під торговою маркою INBLU, які переважно експортуються до країн Європейського Союзу. Великі підприємства виробництва взуття також розташовані в таких містах як Дніпро, Чернігів, Кропивницький, Білгород-Дністровський та ін. [2; 13]. в таблиці 3.

Роздрібний товарооборот торгівлі товарами легкої промисловості представлений

Таблиця 3

Товарна структура роздрібного товарообороту підприємств роздрібної торгівлі товарами легкої промисловості

\begin{tabular}{|l|c|c|c|c|c|c|}
\hline \multirow{2}{*}{ Показники } & \multicolumn{2}{|c|}{2017} & \multicolumn{2}{|c|}{2018} & \multicolumn{2}{|c|}{$2018 / 2017$} \\
\cline { 2 - 8 } & млн.грн & $\begin{array}{c}\text { Структура, } \\
\%\end{array}$ & млн.грн & $\begin{array}{c}\text { Структура, } \\
\%\end{array}$ & млн.грн & $\begin{array}{c}\text { Структура, } \\
\%\end{array}$ \\
\hline Товари текстильні та галантерея & 1835,4 & 7,16 & 2391,7 & 7,95 & 556,3 & 0,78 \\
\hline Одяг та білизна з тканин & 12482,7 & 48,72 & 15572,3 & 51,74 & 3089,6 & 3,02 \\
\hline Одяг зі шкіри, хутра, вироби з них & 153,7 & 0,60 & 198,1 & 0,66 & 44,4 & 0,06 \\
\hline $\begin{array}{l}\text { Головні убори (крім хутрових і } \\
\text { трикотажних) }\end{array}$ & 174,2 & 0,68 & 174,5 & 0,58 & 0,3 & $-0,10$ \\
\hline Трикотаж верхній та білизняний & 3181,3 & 12,42 & 3396,9 & 11,29 & 215,6 & $-1,13$ \\
\hline Вироби панчішно-шкарпеткові & 1588,4 & 6,20 & 1733,5 & 5,76 & 145,1 & $-0,44$ \\
\hline Взуття & 5784,3 & 22,58 & 6155 & 20,45 & 370,7 & $-2,13$ \\
\hline $\begin{array}{l}\text { Шкіряні вироби та дорожні } \\
\text { приналежності }\end{array}$ & 421,8 & 1,65 & 474,8 & 1,58 & 53 & $-0,07$ \\
\hline Всього & 25621,8 & 100,00 & 30096,8 & 100,00 & - & - \\
\hline
\end{tabular}

Джерело: складено авторами на основі [8] 
Відповідно до даних таблиці 3, можна зробити висновки, що одяг та білизна 3 тканин користуються найбільшим попитом серед споживачів (51,74\% або 15572,3 млн грн в 2018 р.) Взуття на другому місці по затребуваності з обсягами 6155 млн грн та 20,45 \% в 2018 р. Трикотаж верхній та білизняний складає 3396,9 млн грн або 11,29 \% в структурі реалізованих товарів. Частка інших товарів легкої промисловості становить $16,52 \%$ або 4972,6 млн грн. в таблиці 4.

Регіональна структура товарообороту товарів легкої промисловості представлена

Таблиця 4

Індекси фізичного обсягу роздрібного товарообороту підприємств роздрібної торгівлі за товарними групами у 2019 році

\begin{tabular}{|c|c|c|c|c|}
\hline \multirow[b]{2}{*}{ Область } & \multicolumn{4}{|c|}{ Найменування товарної групи } \\
\hline & $\begin{array}{c}\text { Текстильні товари, } \\
\text { фіранки, гардини, } \\
\text { штори та тюль }\end{array}$ & Одяг & Взуття & $\begin{array}{c}\text { Шкіряні вироби та } \\
\text { дорожні } \\
\text { приналежності }\end{array}$ \\
\hline $\begin{array}{l}\text { Україна, середнє } \\
\text { значення }\end{array}$ & 107,3 & 120,5 & 131,7 & 199,5 \\
\hline Вінницька & 110,2 & 138,4 & 133,4 & 303,9 \\
\hline Волинська & 90,2 & 111,3 & 144,6 & 240,2 \\
\hline Дніпропетровська & 97 & 132,9 & 133,5 & 226,6 \\
\hline Донецька & 127,3 & 119,5 & 115,6 & 234,6 \\
\hline Житомирська & 113,1 & 135,8 & 179,6 & 264 \\
\hline Закарпатська & 91,9 & 106,3 & 135,8 & 228,3 \\
\hline Запорізька & 92,1 & 117,5 & 136,7 & 237,9 \\
\hline Івано-Франківська & 114,9 & 161,5 & 134,8 & 240,4 \\
\hline Київська & 93,8 & 102,5 & 123,9 & 96,7 \\
\hline Кіровоградська & 90,8 & 119,6 & 164,9 & 241,1 \\
\hline Луганська & 91,3 & 157,3 & 142,4 & 304,3 \\
\hline Львівська & 108,8 & 110 & 120 & 281,8 \\
\hline Миколаївська & 92,3 & 94,2 & 108,9 & 168,8 \\
\hline Одеська & 85,8 & 106,5 & 120,3 & 212,1 \\
\hline Полтавська & 116,7 & 122,1 & 156,4 & 272,1 \\
\hline Рівненська & 97,2 & 123 & 117,7 & 235,6 \\
\hline Сумська & 54,9 & 100 & 135,8 & 177,1 \\
\hline Тернопільська & 139,6 & 134,1 & 183,5 & 1731,1 \\
\hline Харківська & 106,9 & 105,4 & 122,8 & 176,8 \\
\hline Херсонська & 96,1 & 115,1 & 108,3 & 201,9 \\
\hline Хмельницька & 104,1 & 132,4 & 186,6 & 224 \\
\hline Черкаська & 129,2 & 112,6 & 193,7 & 257,6 \\
\hline Чернівецька & 64,1 & 107,2 & 127,5 & 420,9 \\
\hline Чернігівська & 109 & 177,5 & 261,3 & 399 \\
\hline м.Київ & 138,6 & 162,2 & 162,1 & 246,4 \\
\hline
\end{tabular}

Джерело: складено авторами на основі [9]

Отже, щорічно зростає потреба в виробах товарів легкої промисловості. Зокрема, шкіряні вироби та дорожні приналежності зазнали найбільшого росту в структурі роздрібного товарообороту України $(+99,5$ \%) у 2019 р. Споживання взуттєвих виробів та одягу зросло на $31,7 \%$ і 20,5\% відповідно, а продаж текстильних товарів на 7,3\%.

Оптовий товарооборот товарами легкої промисловості наведено в таблиці 5. 
Таблиця 5

Структура оптового товарообороту підприємств оптової торгівлі за видами економічної діяльності у 2018-2019 рр.

\begin{tabular}{|l|c|c|c|c|c|c|}
\hline \multirow{2}{*}{\multicolumn{1}{|c|}{ Показники }} & \multicolumn{2}{|c|}{2018} & \multicolumn{2}{|c|}{2019} & \multicolumn{2}{c|}{$2018 / 2017$} \\
\cline { 2 - 7 } & млн грн & Структура, \% & млн грн & $\begin{array}{c}\text { Структура, } \\
\%\end{array}$ & млн грн & $\begin{array}{c}\text { Структура, } \\
\%\end{array}$ \\
\hline $\begin{array}{l}\text { Оптова торгівля } \\
\begin{array}{l}\text { шкірсировиною, } \\
\text { шкурами та шкірою }\end{array}\end{array}$ & 162 & 1,85 & 172 & 1,67 & 10 & $-0,17$ \\
\hline $\begin{array}{l}\text { Оптова торгівля текстильними } \\
\text { товарами }\end{array}$ & 3985,3 & 45,47 & 4459 & 43,41 & 473,7 & $-2,06$ \\
\hline $\begin{array}{l}\text { Оптова торгівля одягом і } \\
\text { взуттям }\end{array}$ & 4618,3 & 52,69 & 5641 & 54,92 & 1022,7 & 2,23 \\
\hline Всього & 8765,6 & 100,00 & 10272 & 100,00 & - & - \\
\hline
\end{tabular}

Джерело: складено авторами на основі [10]

Відповідно до даних таблиці 5 можна зробити висновки, що найбільш затребуваними товарами оптових покупців також є одяг та взуття $(54,92 \%$ в структурі та 5641 млн грн обороту). Торгівля текстильними товарами складає 43,41\% в структурі та 4459 млн грн обороту. Найменша за значенням і за обсягами група шкірсировина, шкіри та шкури - 1,67\% питомої ваги та 172 млн грн. На нашу думку, це пов'язано з тим, що основними потребами оптових покупців є одяг та взуття для персоналу, яке є розхідним матеріалом. Текстильні товари знаходяться на другому місці за споживчим попитом, оскільки в цю групу входить великий спектр товарів повсякденного споживання (постільна білизна, пледи, покривала, тканинні обшивки тощо). Оптова торгівля шкіряною сировиною не $\epsilon$ на високому рівні, адже переважно ця продукція призначена для подальшої переробки, а не для кінцевого споживання. Внутрішнє виробництво шкірсировини не покриває повністю потреб переробної галузі цієї сировини, тому значна експортується із Туреччини, Індії та Китаю.

Висновки. Отже, легка промисловість займає важливу роль в структурі національного господарства, оскільки забезпечує 88 тис. робочих місць на переробних підприємствах із обсягом експортованої продукції в 1184 636,2 тис. дол. США у 2019 р.

Загалом, на основі проведеного аналітичного дослідження, стан розвитку ринку товарів легкої промисловості можемо охарактеризувати як малорозвинутий. Конкуренцію на даному ринку можна оцінювати як високу, адже товари низького цінового сегменту значною мірою покриваються експортом з Китаю та Туреччини, а високого - брендовими виробниками 3 країн ЄС. Крім того, на вітчизняному ринку товарів легкої промисловості присутня велика частка тіньового виробництва $(17,7 \%)$ та торгівлі товарами легкої промисловості. Україна в лідерах із споживання секонд-хенду (3-тє місце в світі), що значно зменшує потенціал для розвитку виробництва галузі. Відповідно, на внутрішньому ринку переважає торгівля імпортними товарами, секондхендом, контрабандними товарами, а торгівля товарами вітчизняного виробництва займає лише $18 \%$.

Зовнішня торгівля текстильними та шкіряними товарами не є збалансованою, про що свідчить від'ємне сальдо експортно-імпортних операцій в 2018-2019 pр. (-1441529,2 та - 1944984,8 тис. дол. відповідно). Вироби з текстилю та матеріали займають найбільш вагому частину у структурі питомої ваги зовнішньою торгівлі товарами легкої 
промисловості - приблизно 76\%, що зумовлене великими обсягами та різноманітним асортиментом товарів першої необхідності в даній групі. Географія товарного імпорту зосереджена переважно у таких країнах як Китай, Польща та Італія, а товарного експорту - у країнах $\mathrm{CC}$.

На нашу думку, основними заходами держави в сфері розвитку виробництва та торгівлі товарами легкої промисловості повинні бути такі:

- детінізація ринку - шляхом спрощення та зменшення податкових платежів для великих підприємств, що стимулюватиме малі та середні підприємства до нарощування виробничих потужностей;

- зменшення потоків вживаних речей - за допомогою впровадження посиленого контролю гуманітарної допомоги на стадії ввезення та розподілу продукції в організаціях;

- захист національних виробників текстильної та шкіряної галузі, що матиме прояви у створенні програм для доступних кредитів та залученні додаткових інвестицій.

Для розвитку підприємствам слід активно співпрацювати та використовувати напрацювання та інструментарій Української асоціації підприємств легкої промисловості, що допоможе їм знайти шляхи виходу на європейський ринок та посилить внутрішні переваги. Окрім цього, підприємствам доцільно інвестувати в оновлення власних виробничих потужностей та професійне навчання персоналу, що допоможе виготовляти продукцію відповідно до міжнародних стандартів та високих споживчих очікувань.

Середній та малий бізнес має великий потенціал в український реаліях, так як ці підприємства можуть швидше адаптуватися під потреби ринку. До прикладу, в сучасних умовах пандемії коронавірусу деякі підприємства легкої промисловості змінили свою орієнтацію на виготовлення масок та захисних костюмів, відповідно, це збільшує економічну безпеку як підприємств, так і населення держави. Тому основним фокусом розвитку підприємств легкої промисловості повинні бути малі та середні підприємства, які є найбільш гнучкими до ринкових змін.

\section{Список бібліографічного опису:}

1.Мирошніченко О.А., Неліна Н.Г., Феленюк О.В. Експорт одягу до ЄС. Гід для украӥнських підприємців. Київ, 2017. 116 с. URL: https://ukrlegprom.org/ua/export/eksport-odiahu-do-ies-hid-dlia-ukrainskykh-pidpryiemtsiv/ (дата звернення 10.04.2020)

2.Бойко В.С., Тарасова К.І. Аналіз розвитку легкої промисловості України. Статистика - інструмент соціальноекономічних досліджень: збірник наукових студентських праць. 2019. Вип. 5. C. 52-62. URL: http://dspace.oneu.edu.ua/jspui/bitstream/123456789/9328/1/\%D0\%90\%D0\%BD\%D0\%B0\%D0\%BB\%D1\%96\%D0\%B7\%20\%D1 $\% 80 \% \mathrm{D} 0 \% \mathrm{BE} \% \mathrm{D} 0 \% \mathrm{~B} 7 \% \mathrm{D} 0 \% \mathrm{~B} 2 \% \mathrm{D} 0 \% \mathrm{~B} 8 \% \mathrm{D} 1 \% 82 \% \mathrm{D} 0 \% \mathrm{BA} \% \mathrm{D} 1 \% 83 \% 20 \% \mathrm{D} 0 \% \mathrm{BB} \% \mathrm{D} 0 \% \mathrm{~B} 5 \% \mathrm{D} 0 \% \mathrm{~B} 3 \% \mathrm{D} 0 \% \mathrm{BA} \% \mathrm{D} 0 \% \mathrm{BE}$ $\% \mathrm{D} 1 \% 97 \% 20 \% \mathrm{D} 0 \% \mathrm{BF} \% \mathrm{D} 1 \% 80 \% \mathrm{D} 0 \% \mathrm{BE} \% \mathrm{D} 0 \% \mathrm{BC} \% \mathrm{D} 0 \% \mathrm{~B} 8 \% \mathrm{D} 1 \% 81 \% \mathrm{D} 0 \% \mathrm{BB} \% \mathrm{D} 0 \% \mathrm{BE} \% \mathrm{D} 0 \% \mathrm{~B} 2 \% \mathrm{D} 0 \% \mathrm{BE} \% \mathrm{D} 1 \% 81 \% \mathrm{D} 1$ $\% 82 \% \mathrm{D} 1 \% 96 \% 20 \% \mathrm{D} 0 \% \mathrm{~A} 3 \% \mathrm{D} 0 \% \mathrm{BA} \% \mathrm{D} 1 \% 80 \% \mathrm{D} 0 \% \mathrm{~B} 0 \% \mathrm{D} 1 \% 97 \% \mathrm{D} 0 \% \mathrm{BD} \% \mathrm{D} 0 \% \mathrm{~B} 8$.pdf (дата звернення 10.04.2020)

3. Розвиток промисловості для забезпечення зростання та оновлення української економіки: науково-аналітична доповідь / за ред. д-ра екон. наук Дейнеко Л.В.; НАН України, ДУ «Ін-т екон. та прогнозув. НАН України». К., 2018.158 с.

4.Гавриленко Т.В., Бродюк І.В. Перспективи розвитку легкої промисловості України в умовах нестабільного зовнішнього середовища. Економічні горизонти. 2018. № 1(4). С. 28-34. URL: http://eh.udpu.edu.ua/article/view/002834/128214 (дата звернення 10.04.2020)

5.Аналітичні матеріали галузі легкої промисловості. 2019. URL: https://ukrlegprom.org/ua/analytics/ (дата звернення 10.04.2020)

6. Товарна структура зовнішньої $\quad$ торгівлі $\quad$ у $\quad 2018-2019 \quad 2019$.

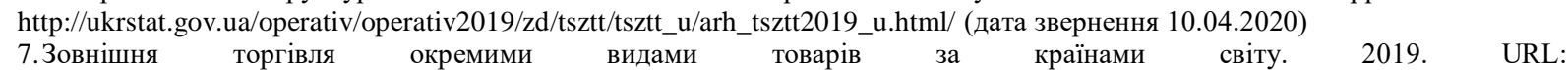
http://ukrstat.gov.ua/operativ/operativ2020/zd/e_iovt/arh_iovt2020.htm (дата звернення 10.04.2020)

8. Товарна структура роздрібного товарообороту підприємств роздрібної торгівлі товарами легкої промисловості. 2019. URL: http://www.ukrstat.gov.ua/operativ/operativ2018/sr/tsrtp/tsrtp2017_u.htm (дата звернення 10.04.2020)

9. Індекси фізичного обсягу роздрібного товарообороту підприємств роздрібної торгівлі за товарними групами у 2019 році. 2019. URL: http://www.ukrstat.gov.ua/operativ/operativ2018/sr/ind_fiz_obs_poz_tovar/arch_ind_fiz_obs_poz_tovar_u.htm (дата звернення 10.04.2020)

10. Структура оптового товарообороту підприємств оптової торгівлі за видами економічної діяльності у 2018 -2019 pp. URL: http://www.ukrstat.gov.ua/operativ/operativ2007/sr/sot/sot_u/sot_rik_u.htm (дата звернення 10.04.2020)

11. В Мінсоцполітики хочуть врегулювати "секонд-хенд", який надходить під виглядом "гуманітарки". 2019. URL: https://www.epravda.com.ua/news/2019/12/3/654417/ (дата звернення 10.04.2020)

12. Українські виробники взуття та одягу на канадському ринку. 2019. URL: https://ukrlegprom.org/ua/export/ukrainskivyrobnyky-vzuttia-ta-odiahu-na-kanadskomu-rynku/ (дата звернення 10.04.2020) 
13. Україна: дорожня карта розвитку галузей виробництва одягу та взуття. J.E. Austin Associates. 2017. URL: https://ukrlegprom.org/files/ukrlegprom-roadmap.pdf (дата звернення 10.04.2020)

\title{
References:
}

1. Miroshnichenko, O.A., \& Nelina, N.G., \& Felenyuk, O.V. (2017) Clothing exports to the EU. Guide for Ukrainian entrepreneurs. Kyiv. 116 p. URL: https://ukrlegprom.org/en/export/eksport-odiahu-do-ies-hid-dlia-ukrainskykh-pidpryiemtsiv/ [in Ukrainian].

2. Boyko, V.S., \& Tarasova, K.I. (2019) Analysis of the development of light industry in Ukraine. Statistics - a tool for socioeconomic research: a collection of scientific student papers. Vol. 5. pp. 52-62. URL: http://dspace.oneu.edu.ua/jspui/bitstream/123456789/9328/1/\%D0\%90\%D0\%BD\%D0\%B0\%D0\%BB\%D1\%96\%D0\%B7\%20 \% D1\% 80\% D0\% BE\% D0\% B7\% D0\% B2\% D0\% B8\% D1\% 82\% D0\% BA\% D1\% 83\% 20\% D0\% BB\% D0\% B5\% D0\% B3\% D0\% BA \% D0\% BE\% D1\% 97\% 20\% D0\% BF\% D1\% 80\% D0\% BE\% D0\% BC\% D0\% B8\% D1\% 81\% D0\% BB\% D0\% BE\% D0\% B2\% D0\% BE \% D1\% 81\% D1\% 82\% D1\% 96\% 20\% D0\% A3\% D0\% BA\% D1\% 80\% D0\% B0\% D1\% 97\% D0\% BD\% D0\% B8.pdf [in Ukrainian].

3. Development of industry to ensure the growth and renewal of the Ukrainian economy: a scientific and analytical report / ed. Dr. Econ. Science Deineko L. NAS of Ukraine, SI "Inst. Of Economics. and predicted. NAS of Ukraine". Kyiv, 2018. 158 p. [in Ukrainian]. 4. Gavrilenko T., \& Brodyuk I. (2018) Prospects for the development of light industry in Ukraine in an unstable environment. Economic horizons. No 1 (4). pp. 28-34. URL: http://eh.udpu.edu.ua/article/view/002834/128214 [in Ukrainian]

5. Analytical materials of light industry. 2019. URL: https://ukrlegprom.org/ua/analytics/ [in Ukrainian].

6. Commodity structure

of foreign trade in

2019. http://ukrstat.gov.ua/operativ/operativ2019/zd/tsztt/tsztt_u/arh_tsztt2019_u.html/ [in Ukrainian].
certain types
of goods
by
country.
2019
URL:

7.

8. Commodity structure of retail trade turnover of enterprises of retail trade in light industry goods. 2019. URL: http://www.ukrstat.gov.ua/operativ/operativ2018/sr/tsrtp/tsrtp2017_u.htm [in Ukrainian].

9. Indices of physical volume of retail trade turnover of retail trade enterprises by product groups in 2019. 2019. URL: http://www.ukrstat.gov.ua/operativ/operativ2018/sr/ind_fiz_obs_poz_tovar/arch_ind_fiz_obs_poz_tovar_u.htm [in Ukrainian].

10. Structure of wholesale trade turnover of wholesale trade enterprises by types of economic activity in 2018-2019 URL: http://www.ukrstat.gov.ua/operativ/operativ2007/sr/sot/sot_u/sot_rik_u.htm [in Ukrainian].

11. The Ministry of Social Policy wants to settle the "second-hand", which comes under the guise of a "humanitarian". 2019. URL: https://www. althoughda.com.ua/news/2019/12/3/654417/ [in Ukrainian].

12. Ukrainian manufacturers of footwear and clothing on the Canadian market. 2019. URL: https://ukrlegprom.org/en/export/ukrainski-vyrobnyky-vzuttia-ta-odiahu-na-kanadskomu-rynku/ [in Ukrainian].

13. Ukraine: a roadmap for the development of clothing and footwear industries. J.E. Austin Associates. 2017. URL: https://ukrlegprom.org/files/ukrlegprom-roadmap.pdf [in Ukrainian].

Дата подання публікації 28.03.2020 p.

УДК 338.24:332

Прус Ю.І., викладач кафедри управління та адміністрування Prus Yu., lecturer of Department of Management and Administration https://orcid.org/0000-0003-0320-0131

\section{КОНЦЕПТУАЛЬНИЙ ПЫЛХІ ДО УПРАВЛІННЯ РОЗВИТКОМ ПРОСТОРОВОГО КАПІТАЛУ}

\author{
Харківський начуіональний університет імені В.Н. Каразіна
}

Статтю присвячено обгрунтуванню концептуального підходу до управління розвитком просторового капіталу, оскільки в умовах сьогодення недостатньо ефективним $є$ застосування стандартних прийомів та інструментів менеджменту при досягненні сталості економічного розвитку. Аналізуючи, систематизуючи та узагальнюючи наукові праці іноземних та вітчизняних дослідників, розглянуто еволюцію концепцій капіталу та простору, запропоновано авторське визначення поняття «просторовий капітал».

Розглянуто альтернативні моделі обгрунтування нерівномірності економічного простору (центрально-периферійна модель, модель чинників «першої» та «другої» природи). Узагальнено показники та методи кількісної оцінки нерівномірності розвитку просторового капіталу, серед яких найбільш прийнятними є індекси Тейла, індекс Аткінсона. Вони дозволяють виявити масштаб, динаміку та структуру нерівномірності розвитку просторового капіталу за кожною компонентою. Запропоновано п'ять груп показників оцінки якості просторового капіталу індустріальних центрів як основних осередків його розвитку, генераторів та ретрансляторів глобальних змін. Доцільність використання структурних показників обгрунтована успішністю реалізації стратегічного плану розвитку Свропейського Союзу «Європа-2020» на засадах соціальної згуртованості та смарт спеціалізації. 